\title{
The Effects of Attachment and Shared Time Between Mother and Child and Self-Esteem on Subjective Well-Being in Late Childhood
}

\author{
Ji-A Bae ${ }^{1}$, Hyun-Sim Doh ${ }^{1}$, Bokyung Park², Min-Jung Kim ${ }^{3}$ \\ Department of Child Development, Ewha Womans University, Seoul, Korea ${ }^{1}$ \\ Department of Education for Child Care, Kyungmin College, Uijeongbu, Korea ${ }^{2}$ \\ Department of Child Welfare, Namseoul University, Cheonan, Korea ${ }^{3}$
모-자녀 애착 및 공유시간과 자아존중감이 학령 후기 아동의 주관적 안녕감에 미치는 영향 \\ 배지아 ${ }^{1}$, 도현심 ${ }^{1}$, 박보경 ${ }^{2}$, 김민정 ${ }^{3}$ \\ 이화여자대학교 아동학과 ${ }^{1}$, 경민대학교 아동보육과 ${ }^{2}$, 남서울대학교 아동복지학과 ${ }^{3}$
}

\begin{abstract}
Objective: This study aimed to examine the effects of attachment and shared time between mother and child and self-esteem on subjective well-being in late childhood.

Methods: A total of 329 fifth and sixth graders in elementary school (183 boys and 146 girls) participated in the study. They responded to questionnaires regarding attachment and shared time between mother and child and the self-esteem and subjective well-being of children. The data were analyzed using SEM.

Results: Attachment and shared time between mother and child had an indirect effect through selfesteem as well as a direct effect on the subjective well-being of children. Children who formed secure attachments and spent more time with their mothers showed a higher level of subjective well-being. In addition, when children kept a good relationship with their mother quantitatively as well as qualitatively, they acknowledged their own capability and value positively, which led to higher subjective well-being.

Conclusion: Findings emphasize that mother-child relationships play significant roles in predicting both the subjective well-being and self-esteem of children. The importance of self-esteem was identified in late childhood based on its relative influence on subjective well-being compared to mother-child relationships.
\end{abstract}

Keywords: mother-child relationships, attachment, shared time, self-esteem, subjective well-being$$
\text { 서론 }
$$

한국방정환재단에서는 2009년부터 매년 유니세프 행복지 수를 모델로 한 국제비교연구를 통해 한국 어린이-청소년 행

Corresponding Author: Bae, Ji-A, Department of Child Development, Ewha Womans University, 52, Ewhayeodae-gil, Seodaemun-gu, Seoul 03760, Korea

E-mail: happy-jia1011@hanmail.net
}

복지수를 발표하고 있다. 물질적 행복, 보건과 안전, 교육, 가 족과 친구관계, 행동과 생활양식, 주관적 행복 등 행복의 6가 지 하위영역 중 우리나라 아동 및 청소년은 2009년부터 2015 년에 이르기까지 계속적으로 주관적 행복 영역에서 가장 낮

(C)The Korean Association of Child Studies

This is an Open Access article distributed under the terms of the Creative Commons Attribution Non-Commercial License (http:// creativecommons.org/licenses/by-nc/4.0) which permits unrestricted noncommercial use, distribution, and reproduction in any medium, provided the original work is properly cited. 
은 점수를 보여주고 있다. 경제협력개발기구(OECD) 국가들 과의 비교에서도 다른 국가들에 비해 주관적 행복 영역에서 2014년까지는 가장 낮은 점수를 보고하다가 2015년에 처음으 로 최하위를 벗어났다. 반면, 물질적 행복, 교육 및 행동과 생 활양식 영역에서는 $\mathrm{OECD}$ 국가들 중 최상위 수준을 보였다 (Youm, Kim, Lee, \& Lee, 2015). 이러한 결과는 우리 사회의 양 면성을 여실히 나타내는 것으로, 이전에 비해 상당히 풍요로 워진 환경 속에서 살아가고 있음에도 불구하고 자신의 삶에 만족하지 못하거나 내면적으로 어려움을 경험하는 아동이 적 지 않음을 의미한다. 따라서 아동의 심리적 복지를 증진시키 기 위해서는 아동의 행복감이나 안녕감과 같은 주관적 측면에 대한 학문적 관심이 절실히 요구된다.

이러한 맥락에서 연구자들은 인간의 정신건강을 강조하 며, 행복(Bradburn, 1969)을 비롯하여 주관적 안녕감(Diener, 1984), 심리적 안녕감(Ryff, 1989), 삶에 대한 만족(Diener, Emmons, Larsen, \& Griffin, 1985; D. C. Shin \& Johnson, 1978) 등과 같은 인간의 내적 차원에 주목하고 있다. 이에 대한 초 기 연구들은 주로 성인을 대상으로 수행되었으나(e.g., Jeon \& Lim, 2002; Jo \& Cho, 2004; M. Kim, Kim, \& Cha, 2001), 최근 에는 청소년(e.g., H. J. Lee, Lee, \& Choe, 2008; E. Park \& Choi, 2014)이나 아동(e.g., Bea, Doh, Rhee, \& Shin, 2015; Choi, 2010; Yoo, Park, \& Doh, 2015)을 대상으로 한 연구들도 보고되고 있 다. 주관적 안녕감은 긍정적 정서를 많이 느끼고 자신의 유능 성과 대인관계를 긍정적으로 지각하는 것을 의미하는 것으로 (Bak \& Song, 2007), 아동이 경험하는 주관적 안녕감이나 행복 감은 아동의 현재 발달 및 적응을 설명하는 중요한 지표가 될 뿐만 아니라 청소년기나 성인기 발달 및 적응을 예측할 수 있 다. 특히 학령 후기에 속하는 초등학교 고학년은 발달단계 특 성상 급격한 신체발달과 정신적 성숙이 진행되는 과정에서 갈 등과 혼란을 겪기 쉬우므로, 이 시기 아동의 주관적 안녕감 증 진은 그들이 보다 적응적인 청소년기를 맞이할 수 있도록 돕 기 위한 중요한 과제이다.

주관적 안녕감에 대한 선행 연구들은 주로 주관적 안녕감 의 선행 요인들을 밝히는 데 초점을 두고 있다. 이러한 요인들 가운데 개인 내적 요인과 개인 외적 요인은 대표적 두 가지 요 인에 속한다. 개인 내적 요인의 경우 자아존중감(Choi, 2010; H. Lee \& Moon, 2012; Yoo et al., 2015), 자아탄력성(Ahn, Oh, $\&$ Kim, 2011; H. Lee \& Moon, 2012), 낙관성(Joo \& Park, 2013; Noh \& Shin, 2014; Y. Roh \& Kim, 2012), 성격강점(Kang \& Chang, 2013) 등이 포함되며, 개인 외적 요인으로는 부모애착 (Ahn et al., 2011; H. Lee \& Moon, 2012; Y. Roh \& Kim, 2012),
부모의 양육행동(Bea et al., 2015; Joo \& Park, 2013; J. Lee \& Lee, 2007), 부모 간 갈등(J. Lee \& Lee, 2007; Min, 2008), 가족 건강성(Koo \& Kim, 2014), 또래관계(Bea et al., 2015; Yoo et al., 2015), 사회적 지지(H. Cho, 2011; Kang \& Chang, 2013; J. Lee \& Lee, 2007; H. C. Park, Kim, \& Hong, 2011) 등을 들 수 있다. 이에 더해, 최근의 몇몇 연구들은 개인 외적 요인이 직접적으 로 뿐만 아니라 개인 내적 요인을 매개로 하여 간접적으로도 주관적 안녕감에 영향을 미침을 밝히고 있다(Kang \& Chang, 2013; H. Lee \& Moon, 2012; Y. Roh \& Kim, 2012; Yoo et al., 2015). 이러한 연구들 가운데 한 연구(Yoo et al., 2015)에서는 학령 후기 아동의 또래관계가 주관적 안녕감에 직접적 영향을 미칠 뿐만 아니라 자아존중감을 통해 간접적으로도 영향을 미 침을 발견하였으며, 특히 자아존중감이 주관적 안녕감을 설명 하는 강력한 예측 요인임을 보고하였다. 그러나 선행 변인으 로서의 또래관계가 자아존중감을 설명하는 정도는 약 $10 \%$ 정 도에 불과하여, 학령 후기 아동의 자아존중감에 영향을 미치 는 또 다른 변인의 영향력을 가정하게 한다. 또 다른 변인으로 는 이 시기 아동에게 여전히 중요한 개인 외적 요인 중 하나인 부모-자녀관계를 고려해볼 수 있다. 이와 관련하여, 가족 구성 원 간의 유대 및 의사소통과 같은 가정 분위기는 학령 후기 아 동의 자아존중감에 또래지지보다 더 큰 영향을 미쳤으며(Jung $\&$ Park, 2010), 어머니의 애정적 양육행동은 또래수용도에 비 해 학령 후기 아동의 자아존중감의 전반적인 영역과 더 높은 상관을 보이는 것으로 보고된 바 있다(S. Lee \& Choi, 2003).

부모는 자녀가 처음으로 접하는 사회적 환경이며, 이 중 어 머니는 주 양육자로서 양육을 통해 자녀의 발달 및 적응에 커 다란 영향을 미치는 것으로 잘 알려져 왔다. 이러한 측면에 서 아동의 주관적 안녕감에 관심 있는 연구자들 역시 어머니 의 영향력에 주목하고 있으며(Ahn et al., 2011; Bea et al., 2015; Joo \& Park, 2013; S. Lee, Doh, Choi, \& Ku, 2010; J. Lee \& Lee, 2007), 이와 관련하여 어머니와의 애착은 대표적으로 다루어 진 요인이다. 애착은 일반적으로 주 양육자인 어머니와 자녀 간에 형성되는 강한 정서적 유대로(Ainsworth, Blehar, Waters, \& Wall, 1978; Bowlby, 1988), 많은 선행 연구들에서 어머니와 안정적인 애착을 맺은 학령 후기 아동은 심리사회적으로 보다 잘 적응하고 건강하게 발달하는 것으로 보고되고 있다(Jhon \& Yoo, 2014; C. Kim, Han, \& Cho, 2013). 실제로 학령 후기 아 동을 대상으로 한 연구들에서는 모-자녀 애착이 높은 학령 후 기 아동의 경우 행복감 또는 주관적 안녕감 역시 높았으며(Y. Roh \& Kim, 2012; Seong \& Kim, 2015), 이러한 결과는 청소년 을 대상으로 한 연구들에서도 유사하게 보고되었다(S. Cho \& 
Jin, 2015; Ko, 2008). 특히 최근 연구에서 아동이 맺는 주요한 관계들, 즉 어머니, 아버지, 또래, 교사와의 애착 가운데 특히 어머니와의 애착이 초등학교 4-6학년 아동의 행복감을 가장 잘 설명하는 변인으로 발견된 연구결과(Seong \& Kim, 2015) 에 근거할 때, 학령 후기 아동의 주관적 안녕감 발달과 관련하 여 모-자녀 애착의 중요성은 강조할 만하다.

모-자녀 애착이 어머니와 자녀 간 관계의 질적 측면을 설명 하는 개념이라면, 모-자녀 공유시간은 양자 관계의 양적 측면 으로 볼 수 있다. 모-자녀 공유시간은 동일한 장소에서 어머 니와 자녀가 동일한 활동에 함께 참여하는 시간을 의미한다 (Crouter, Head, McHale, \& Tucker, 2004; S. Lee \& Lee, 1998). 그러나 모-자녀 공유시간은 아동의 사회.정서적 발달과의 관 련성보다는 그 현황에 대한 실태조사 수준에 머무르는 경향 이 있어, 모-자녀 공유시간과 주관적 안녕감 간의 관련성을 직 접적으로 밝힌 연구는 매우 드물다. 몇몇 관련 연구들을 살 펴보면, 온 가족이 함께 식사하는 경우가 많은 초등학교 5-6 학년 아동은 만족감이나 행복감을 높게 지각하였으며(Sung $\&$ Kwon, 2010) 가족과 여가활동을 자주 할수록 청소년이 높 은 심리적 복지감을 경험하였다(J. Lee, 2012). 국외의 경우에 도 청소년의 가족 공유시간과 심리사회적 적응 간의 관련성 을 밝힌 연구결과들이 드물게나마 보고된 바 있다(Crouter et al., 2004; Eisenberg, Olson, Neumark-Sztainer, Story, \& Bearinger, 2004; Offer, 2013). 이러한 선행 연구결과들을 근거로, 본 연구 는 아동이 주 양육자인 어머니와 함께 하는 시간이 학령 후기 아동의 주관적 안녕감에 영향을 미치리라 예측하였다.

앞서 언급한 것처럼, 선행 연구들은 개인 외적 요인과 아동 의 주관적 안녕감 간의 관계에서 개인 내적 요인의 매개적 역 할을 발견하였다(Kang \& Chang, 2013; H. Lee \& Moon, 2012; Y. Roh \& Kim, 2012; Yoo et al., 2015). 이는 모-자녀 애착 및 모자녀 공유시간이 직접적으로 뿐만 아니라 개인 내적 요인을 통해 간접적으로도 아동의 주관적 안녕감에 영향을 미칠 수 있음을 가정하게 한다. 아동의 주관적 안녕감과 관련하여 연 구자들이 관심을 가져온 개인 내적 요인들 가운데 자아존중 감은 자기 자신에 대한 지각이나 평가, 감정 등을 의미한다 (Harter, 1982). 자아존중감은 행복감이나 주관적 안녕감에 대 한 설명력이 상당히 크다는 점(Baumeister, Campbell, Krueger, \& Vohs, 2003; Campbell, 1981; Diener \& Diener, 1995)에서 모자녀 애착 및 모-자녀 공유시간과 아동의 주관적 안녕감 간의 관계를 매개하는 변인으로 가정할 수 있다. 모-자녀 애착 및 모-자녀 공유시간을 동시에 고려하여 이러한 두 가지 변인이 자아존중감을 통해 아동의 주관적 안녕감에 미치는 영향을 살
펴본 연구는 발견하기가 쉽지 않다. 다만, 두 가지 변인 가운 데 애착을 포함한 선행 연구들이 최근 몇몇 보고되고 있는데, 부모와의 애착이 높은 학령 후기 아동은 자아존중감이 높았 으며 이는 다시 높은 안녕감으로 연결되었다(H. Lee \& Moon, 2012). 중학교 1학년생을 대상으로 한 연구에서는 부모, 또래, 교사 및 이웃을 포함한 사회적 관계가 긍정적인 초기 청소년 이 높은 자아존중감을 나타내었고 이는 삶의 만족도 역시 높 게 지각하는 것으로 이어졌다(Sihn, Jeon, \& Yoo, 2012). 이러한 연구들은 비록 본 연구에서처럼 주 양육자와의 관계인 모-자 녀관계에 초점을 두기 보다는 부모-자녀관계나 부모, 또래, 교 사 및 이웃을 포함한 사회적 관계와 같이 다소 폭넓은 개념을 다루고 있으나, 본 연구와 유사한 맥락에서 개인 내적 변인인 자아존중감의 매개적 역할을 확인하였다.

이 외에, 모-자녀 애착 및 모-자녀 공유시간과 아동의 자아 존중감 간의 관련성과 아동의 자아존중감과 주관적 안녕감 간의 관련성을 밝힌 선행 연구들을 통해서도 모-자녀 애착 및 모-자녀 공유시간이 아동의 주관적 안녕감에 미치는 영향에 서 자아존중감의 매개적 역할을 유추해볼 수 있다. 이를 각각 의 경로별로 나누어 살펴보면, 먼저 모-자녀 애착 및 모-자녀 공유시간은 자녀의 자아존중감에 영향을 미쳐, 어머니와의 애 착이 안정적이라고 지각하는 초등학교 5-6학년 아동은 자아 존중감이 높았으며(S. Kim \& Lee, 2014; H. K. Park \& Kwon, 2012), 등하교 시 혹은 잠자리에 들기 전에 어머니가 집에 있 는 경우가 많고 어머니와 함께 대화를 나누거나 영화관이나 박물관 등에 가는 것과 같은 활동을 자주 할수록 청소년의 자 아존중감은 높았다(Bulanda \& Majumdar, 2009). 또한, 아동의 자아존중감과 주관적 안녕감 간에도 밀접한 관련성이 보고되 어, 자아존중감이 높은 초등학교 5-6학년 아동은 주관적 안녕 감 역시 높게 지각하였다(Choi, 2010; Yoo et al., 2015).

종합하면, 학령 후기 아동의 또래관계와 주관적 안녕감 간 의 관계에서 자아존중감의 매개적 역할을 보고한 최근 연구 (Yoo et al., 2015)를 확장하여, 본 연구는 주 양육자인 어머니와 의 관계에 초점을 두어 학령 후기 아동의 모-자녀관계와 주관 적 안녕감 간의 관계에서 자아존중감의 매개적 역할을 탐색하 였다. 즉, 모-자녀관계를 질적 측면인 모-자녀 애착과 양적 측 면인 모-자녀 공유시간으로 구분하여, 모-자녀 애착 및 모-자 녀 공유시간이 아동의 주관적 안녕감에 미치는 직접적 영향과 자아존중감을 통해 미치는 간접적 영향을 살펴봄으로써, 모자녀관계가 아동의 주관적 안녕감에 영향을 미치는 경로를 확 인하였다. 본 연구에서 선정한 연구문제와 연구모형은 다음과 같다(Figure 1). 


\section{연구문제 1}

모-자녀 애착 및 모-자녀 공유시간은 학령 후기 아동의 주관적 안녕감에 직접적 영향을 미치는가?

\section{연구문제 2}

모-자녀 애착 및 모-자녀 공유시간은 자아존중감을 통해 학령 후기 아동의 주관적 안녕감에 간접적 영향을 미치는가?

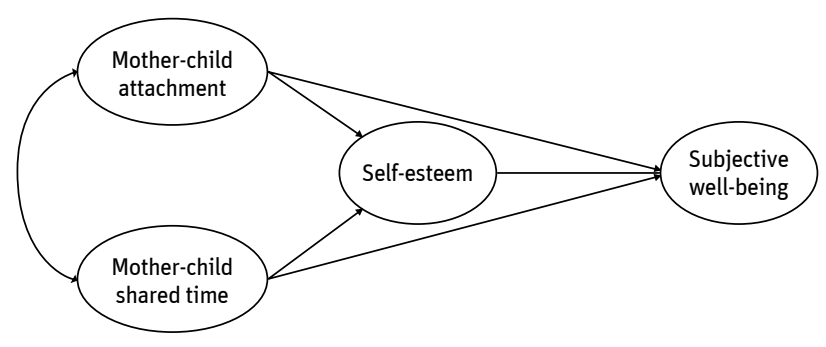

Figure 1. Pathways from mother-child attachment and motherchild shared time to subjective well-being through self-esteem.

\section{연구방법}

\section{연구대상}

본 연구의 대상은 대구광역시 소재 초등학교에 재학 중인 329 명의 5, 6학년 남녀 아동들이다. 연구대상을 이와 같이 선 정한 이유는 일반적으로 청소년기보다 학령기 아동이 부모 의 영향을 더 많이 받는다는 점(Karademas, Peppa, Fotiou, \& Kokkevi, 2008)과 학령 후기부터 인지발달로 인해 논리적이고 추상적인 사고가 가능해져서, 자신 및 환경에 대한 평가를 명 료히 하게 되고, 객관적으로 자신의 정서와 느낌을 표현할 수 있다는 점(Montemayor \& Eisen, 1977)에 근거하였다. 본 연구 대상의 사회인구학적 특성을 살펴보면, 아동의 성별은 남아 가 183명(55.6\%), 여아가 146명(44.4\%)이었고, 학년은 초등학 교 5학년이 198명(60.2\%), 6학년이 131명(39.8\%)이었으며, 출 생순위는 외동이가 36 명(10.9\%), 첫째가 102 명(31.0\%), 둘째 가 158 명(48.0\%), 셋째 이상이 33명(10.0\%)이었다. 부모의 연 령과 관련하여, 아버지는 41-50세가 261명(79.4\%)이었으며, 어머니는 36-45세가 274 명(83.0\%)이었다. 부모의 교육수준의 경우, 아버지는 대학교 졸업이 152 명(46.2\%)으로 가장 많았고 그 다음은 고등학교 중퇴 또는 졸업이 78명(23.7\%)이었으며, 어머니도 대학교 졸업이 148 명(45.0\%)으로 가장 많았고 그 다 음은 고등학교 중퇴 또는 졸업이 85 명(25.\%)이었다. 부모의
직업은 아버지의 경우 회사원, 은행원, 공무원, 교사가 140 명 $(39.5 \%)$ 으로 가장 많았고, 어머니의 경우 전업주부가 121 명 $(36.8 \%)$ 로 가장 많았다.

\section{연구도구}

본 연구에 사용된 조사도구는 학령 후기 아동의 모-자녀 애착, 모-자녀 공유 시간, 자아존중감 및 주관적 안녕감을 측정하기 위한 네 가지 척도로 구성되어 있다. 모든 척도는 아동 자신에 의해 보고되었다.

$$
\text { 모-자녀 애착 }
$$

모-자녀 애착은 Armsden과 Greenberg (1987)의 부모 및 또래 애착 척도(Inventory of Parent and Peer Attachment [IPPA])를 $\mathrm{Ok}$ (1998)이 번안 · 수정한 척도 가운데 부모 애착에 해당하는 문항을 사용하여 측정하였다. 본 척도는 의사소통(9문항), 신 뢰감(10문항), 소외(6문항)의 세 가지 하위요인으로 구성되어 있다(총 25문항). 문항의 예를 보면, 의사소통 요인에는 "우리 어머니는 나의 어려움을 이야기하도록 격려해주신다." "나는 어머니에게 나의 어려움과 근심거리에 대해 말씀 드린다.” 등 이 포함되고, 신뢰감 요인에는 "우리 어머니는 나의 판단을 신 뢰하신다." "우리 어머니는 내 감정을 존중해주신다.” 등의 문 항이 있으며, 소외 요인에는 "나는 어머니로부터 별 관심을 받 지 못한다.”, "어머니는 내게 너무 많은 걸 기대하신다.” 등의 문항이 포함되어 있다. 각 문항은 거의 그렇지 않다(1점), 그렇 지 않은 편이다(2점), 그런 편이다(3점), 매우 그렇다(4점)의 4 점 Likert 척도로 측정하였으며, 점수가 높을수록 모-자녀 애착 이 긍정적인 것을 의미한다. 내적합치도(Cronbach's $\alpha$ )에 의한 신뢰도를 산출한 결과, 신뢰감 요인과 소외 요인에서 전체 신 뢰도를 낮추는 각각 한 문항을 제외한 후, 총 23 문항을 분석에 사용하였다. Cronbach's $\alpha$ 는 의사소통은 .89 , 신뢰감은 .86 , 소 외는 .67이었다.

\section{모-자녀 공유시간}

본 연구는 모-자녀 공유시간을 여가시간 척도와 식사시간 척 도를 사용하여 측정하였다. 모-자녀 여가시간은 Kwon (2011) 의 아동기 가족의 여가시간 척도를 모-자녀관계에 맞게 수정 한 척도를 사용하여 측정하였다. 본 척도는 문화예술 관람. 참 여활동(박물관.미술관 관람, 영화감상, 악기연주, 사진촬영, 
전통예술 배우기), 스포츠 관람·참여활동(스포츠 관람, 각종 운동하기), 관광활동(국내외 여행, 놀이공원가기, 답사.탐사 등 체험활동), 취미.오락활동(낚시·등산 등 취미활동, 장기.바 둑, 함께 장보기.쇼핑하기, 요리 함께 하기, 외식, 노래방 가기, 음악 감상, 컴퓨터 오락.게임, 주말농장, 책보기, 도서관 가기), 휴식활동(산책, 목욕.사우나.찜질방, TV 보기, 비디오 보기), 기타 사회활동(봉사활동, 종교생활, 친구.친척 방문하기)에 대한 28문항으로 구성되어 있다. 각 문항은 전혀 하지 않는다 (1점), 1년에 1-2번(2점), 6개월에 1-2번(3점), 한 달에 1-2번(4 점), 일주일에 1-2번(5점), 거의 매일(6점)까지의 6점 Likert 척 도로 측정되며, 점수가 높을수록 모-자녀 여가시간이 많음을 의미한다. 모-자녀 여가시간의 Cronbach's $\alpha$ 는 .91이었다. 모자녀 식사시간은 Sung과 Kwon (2010)의 연구에서 온가족이 함께하는 식사 빈도를 측정하기 위해 사용한 척도를 모-자녀 관계에 맞게 수정하여 측정하였다. 본 척도는 아침식사와 저 녁식사에 대한 2문항으로 구성되고, 각 문항은 전혀 하지 않 는다(1점), 일주일에 1-2회(2점), 일주일에 3-4회(3점), 일주일 에 5-6회(4점), 일주일에 7회(5점)까지의 5점 Likert 척도로 측 정되며, 점수가 높을수록 모-자녀 식사시간이 많음을 의미한 다.

\section{자아존중감}

자아존중감은 Rosenberg (1965)의 자아존중감 척도(Self-Esteem Scale)를 Y. H. Kim (2005)이 번안한 척도를 사용하여 측정하 였다. 본 척도는 단일 요인으로 총 10 문항으로 구성된다. 문항 의 예로는 "나는 남들만큼 가치 있는 사람이다.", "나에게는 좋 은 점이 많이 있다.” 등이 있으며, 각 문항에 대한 응답은 거의 그렇지 않다(1점), 그렇지 않은 편이다(2점), 그런 편이다(3점), 매우 그렇다(4점)의 4점 Likert 척도로 측정되었다. 부정적 의 미의 문항은 역채점하였으며, 점수가 높을수록 아동의 자아존 중감이 높음을 의미한다. 이 척도의 Cronbach's $\alpha$ 는 .85이었다.

\section{주관적 안녕감}

아동의 주관적 안녕감은 Bak과 Song (2007)의 주관적 안녕 척 도를 사용하여 측정하였다. 이 척도는 Diener $(1984,1996)$ 와 Ryff (1989) 등의 연구를 참고해, Bak과 Hong (2004)이 개발한 척도를 수정·보완한 것이다. 원 척도는 정적 관계안녕, 부적 관 계안녕, 정적 정서안녕, 부적 정서안녕, 정적 효능안녕, 부적 효능안녕의 6 개 하위요인으로 구성되어 있다( 24 문항). 본 연
구는 주관적 안녕감의 정적인 측면에 초점을 두고자, 정적 관 계안녕(4문항), 정적 정서안녕(4문항), 정적 효능안녕(4문항) 에 속한 12 문항만을 사용하였다. 이는 주관적 안녕감을 구성 하는 긍정적 정서와 부정적 정서 가운데, 긍정적 정서가 적 응적 행동을 보다 정확하게 예언한다는 점(Watson \& Clark, 1984)과 정적 안녕에 대한 3 개 하위요인으로 전반적인 안녕감 을 측정할 수 있다는 연구결과(Bak \& Song, 2007)에 근거한 것 이다.

각 하위요인별로 문항의 내용을 살펴보면, 관계안녕 요인 은 자신의 대인관계를 긍정적으로 평가하는 지를 측정하며, “주변 사람들이 나를 좋아한다.", "같이 있기만 해도 좋은 사람 이 있다.”와 같은 문항으로 구성되어 있고, 정서안녕 요인에는 “삶에서 편안함을 느낀다.", “생활에서 기쁨을 느낀다.”와 같 은 자신의 정서에 대해 긍정적으로 평가하는 문항이 포함되 어 있다. 효능안녕 요인은 자신의 유능성에 대해 긍정적으로 평가하는 지를 측정하며, "어려운 과제도 잘 해결할 수 있다.", “매사를 잘 처리할 자신이 있다.”와 같은 문항을 포함한다. 각 문항은 거의 그렇지 않다(1점), 그렇지 않은 편이다(2점), 그런 편이다(3점), 매우 그렇다(4점)의 4점 Likert 척도로 측정되며, 점수가 높을수록 아동의 주관적 안녕감이 높음을 의미한다. 각 요인별 Cronbach's $\alpha$ 는 관계안녕이 .72, 정서안녕이 .91, 효 능안녕이 .83 이었다.

\section{연구절차}

본 조사는 대구시 소재의 5 곳 초등학교에서 학교장의 동의하 에 2013년 7월에 실시되었다. 연구자가 해당 초등학교를 직 접 방문하여 각 반 담임교사에게 연구목적과 응답시의 유의사 항 등을 설명한 뒤, 이들의 도움을 받아 18 개 학급의 아동들에 게 질문지를 배부하였다. 아동들은 질문지 배부 당일, 담임교 사의 지시 하에 직접 질문에 응답했으며, 질문지는 다음 날에 회수되었다. 응답에 소요된 시간은 약 20 분이었다. 배부된 총 386 부의 질문지 중에 364 부가 회수되었으며( $94 \%$ 의 회수율), 회수된 질문지 중 현재 어머니와 함께 살고 있지 않은 아동의 질문지와 불성실하게 응답된 질문지 35 부를 제외하고 329 부 를 본 분석에 사용하였다.

\section{자료분석}

수집된 자료는 SPSS 21.0 (IBM Co., Armonk, NY)과 AMOS 21.0 (IBM Co., Chicago, IL) 프로그램을 사용하여 분석되었다. 
먼저, SPSS 21.0 을 이용하여 연구대상의 사회인구학적 특성을 알아보기 위해 빈도와 백분율을 산출하였고, 조사도구의 신 뢰도를 살펴보기 위해 Cronbach's $\alpha$ 계수에 의한 내적합치도 를 산출하였으며, 연구변인들 간의 상관관계를 확인하기 위해 Pearson의 적률상관계수를 산출하였다. 다음으로, 모-자녀 애 착 및 공유시간과 자아존중감이 아동의 주관적 안녕감에 미치 는 이론적 모형을 검증하기 위해서 AMOS 21.0을 이용하여 구 조방정식 모형(Structural Equation Modeling [SEM]) 분석하였 다. 우선 모형의 적합도를 검증한 후, 연구변인 간 경로를 탐색 하였으며, 각 변인들 간의 직.간접효과를 확인하는 과정에서 간접효과의 유의도는 부트스트래핑(Bootstrapping)을 통하여 검증하였다.

\section{연구결과}

\section{측정변인들 간 상관관계}

학령 후기 아동의 모-자녀 애착, 모-자녀 공유시간, 자아존중 감, 그리고 주관적 안녕감 간의 경로를 구조방정식 모형으로
분석하기에 앞서, Pearson의 적률상관계수를 산출하여 측정 변인들 간의 상관관계를 살펴보았다. 그 결과, 모든 측정변인 들 간에 유의한 상관이 나타났다(Table 1). 먼저, 모-자녀 애착 의 하위요인인 의사소통 및 신뢰감과 아동의 주관적 안녕감 의 세 가지 하위요인인 관계안녕, 정서안녕 및 효능안녕은 서 로 정적 상관을 나타냈으며 $(r s=.45 \sim .61, p<.001)$, 소외는 아 동의 주관적 안녕감의 하위요인들과 부적 상관을 보였다( $r \mathrm{~s}=$ -.25 -.40, $p$ <.001). 즉, 아동은 어머니와 편하고 자유롭게 의 사소통하며 어머니에게 신뢰감을 가질수록, 높은 주관적 안녕 감을 경험하는 반면에, 어머니와의 관계에서 소외감을 느낄수 록 주관적 안녕감을 낮게 지각하였다. 또한, 모-자녀 공유시간 의 하위요인인 여가시간 및 식사시간과 아동의 주관적 안녕감 의 모든 하위요인들 역시 서로 정적 상관을 보여 $(r s=.22 \sim .43$, $p<.001)$, 어머니와 함께 여가시간과 식사시간을 많이 보낼수 록, 아동의 주관적 안녕감이 높았다. 다음으로, 자아존중감과 주관적 안녕감의 모든 하위요인들 간에도 정적인 상관이 나타 나( $r s=.56 \sim .61, p<.001)$, 아동은 자아존중감이 높을수록 자 신의 대인관계, 정서 상태 및 능력에 대해 보다 긍정적으로 지 각하였다. 마지막으로, 모-자녀 애착 및 공유시간과 아동의 자 아존중감 간의 상관관계에서는 모-자녀 애착의 하위요인 중

Table 1

Correlations Among Mother-Child Attachment, Mother-Child Shared Time, Self-Esteem, and Subjective Well-Being

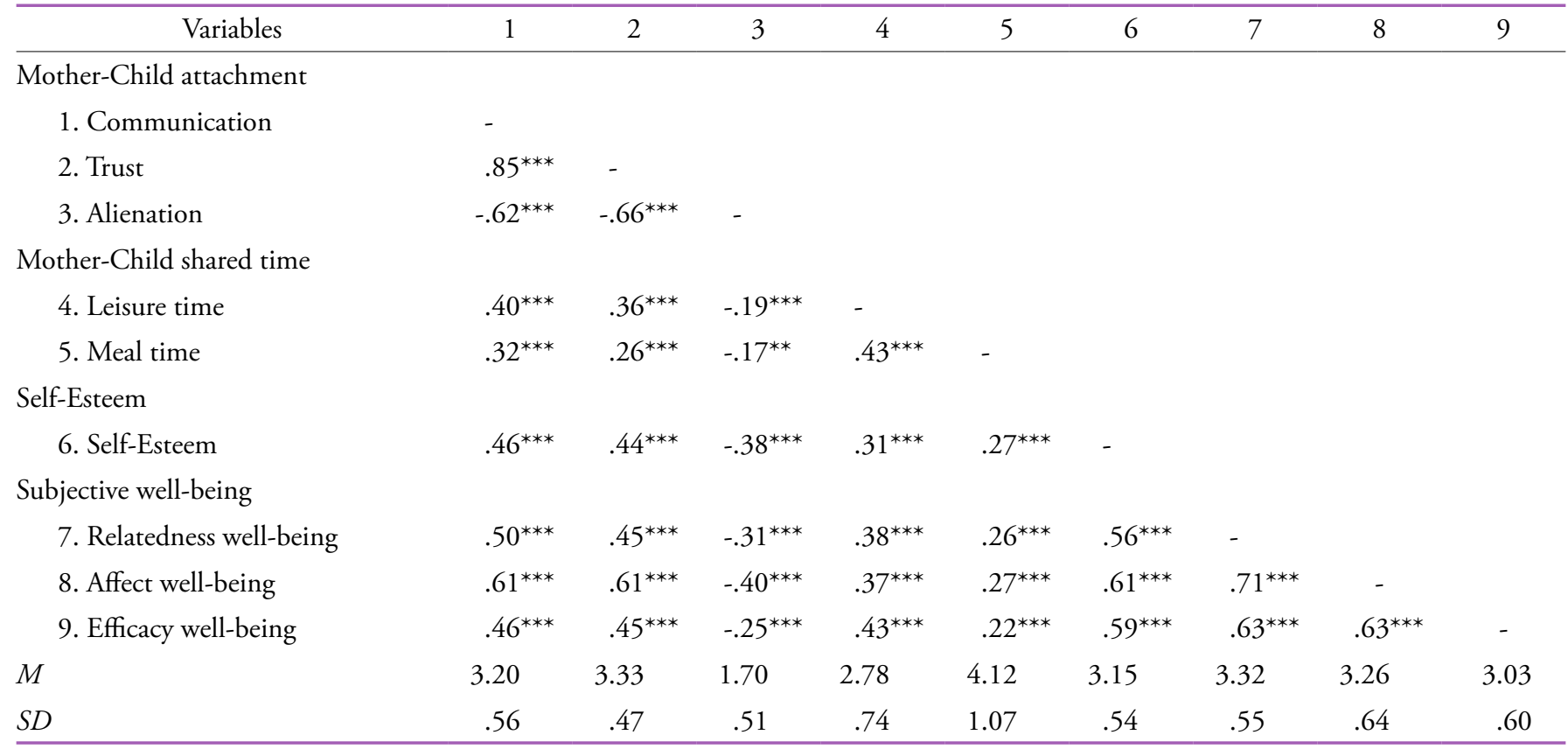

Note. $N=329$.

${ }^{* *} p<.01 .{ }^{* * *} p<.001$. 
에 의사소통과 신뢰감의 점수가 높을수록, 아동의 자아존중감 도 높게 나타났다(의사소통: $r=.46, p<.001$; 신뢰감: $r=.44$, $p$ <.001). 즉, 어머니와 원활하게 의사소통을 하고, 어머니에 대한 신뢰가 좋을수록, 아동은 자신의 가치를 높게 지각했다. 반면, 소외 점수가 높을수록 아동의 자아존중감은 낮았다 $(r=$ $-.38, p<.001)$. 또한 모-자녀 공유시간의 하위요인인 여가시간 과 식사시간 역시 아동의 자아존중감과 정적 상관을 보여, 아 동이 어머니와 여가 및 식사시간을 많이 보낼수록, 자아존중 감을 높게 보고하였다(여가시간: $r=.31, p<.001$; 식사시간: $r$ $=.27, p<.001)$.

\section{측정모형 분석}

연구모형의 구조적 관계를 검증하기에 앞서, 학령 후기 아동 의 모-자녀 애착, 모-자녀 공유시간, 아동의 자아존중감, 그리 고 아동의 주관적 안녕감을 설명하는 측정변인들에 대한 타 당성을 확인하기 위해 확인적 요인분석을 실시하였다. 측정 모형의 적합도는 $\chi^{2}=59.577(d f=22, p<.001), \chi^{2} / d f=2.708$,
$\mathrm{NFI}=.963, \mathrm{TLI}=.961, \mathrm{CFI}=.976, \mathrm{RMSEA}=.072$ 로 나타났 다(Table 2). 이 때, $\chi^{2}$ 값은 표본의 수에 민감하게 영향을 받 을 수 있어 다른 적합도 지수와 함께 고려하여 적합도를 평가 하였다(G. S. Kim, 2011). 그 결과, $\chi^{2} / d f$ 는 3보다 작고(Kline, 1998), NFI, TLI, CFI는 .90보다 커야 하며(S. Hong, 2000), $\mathrm{RMSEA}$ 는 .80보다 작아야한다는(Browne \& Cudeck, 1993) 적 합도 기준을 모두 충족하여, 본 연구의 측정모형은 그 적합 성이 검증되었다. 또한 본 측정모형에서는 모든 요인부하량 $(\beta)$ 의 절대값이 .40 이상이었고 C.R. (Critical Ratio) 값도 모 두 유의하였으므로, 모든 측정변인들이 잠재변인의 개념 을 적절하게 설명하는 것으로 확인되었다(Table 3, Figure 2).

\section{구조모형 분석}

모-자녀 애착 및 공유시간과 자아존중감이 아동의 주관적 안 녕감에 미치는 경로를 확인하기 위해 구조모형의 적합도를 검증하였다. 그 결과, $\chi^{2}=59.577(d f=22), \chi^{2} / d f=2.708, \mathrm{NFI}$ $=.963, \mathrm{TLI}=.961, \mathrm{CFI}=.976, \mathrm{RMSEA}=.072$ 로 적절한 수준

Table 2

Fit Indices of the Measurement Model

\begin{tabular}{ccccccc}
\hline Model & $\chi^{2}$ & $d f$ & $\chi^{2} / d f$ & NFI & TLI & $\begin{array}{c}\text { RMSEA } \\
\text { CFI }\end{array}$ \\
$\begin{array}{c}\text { Measurement } \\
\text { model }\end{array}$ & $59.577^{* * *}$ & 22 & 2.708 & .963 & .961 & .072 \\
\hline
\end{tabular}

Note. $N=329$.

${ }^{* * *} p<.001$.

Table 3

Factor Loadings of the Measurement Model

\begin{tabular}{|c|c|c|c|c|c|}
\hline Latent variables & Observed variables & $B$ & $\beta$ & S.E. & C.R. \\
\hline \multirow[t]{3}{*}{ Mother-child attachment } & Communication & 1.000 & .917 & - & - \\
\hline & Trust & .842 & .926 & .035 & $24.221^{* * *}$ \\
\hline & Alienation & .683 & .692 & .045 & $15.081^{* * *}$ \\
\hline \multirow[t]{2}{*}{ Mother-child shared time } & Leisure time & 1.000 & .775 & - & - \\
\hline & Meal time & .710 & .550 & .113 & $6.273^{* * *}$ \\
\hline Self-esteem & Self-esteem & .460 & .928 & - & - \\
\hline \multirow[t]{3}{*}{ Subjective well-being } & Relatedness well-being & 1.000 & .806 & - & - \\
\hline & Affect well-being & 1.263 & .867 & .074 & $17.142^{* * *}$ \\
\hline & Efficacy well-being & 1.037 & .755 & .071 & $14.584^{* * *}$ \\
\hline
\end{tabular}

Note. $N=329$.

${ }^{* * *} p<.001$. 


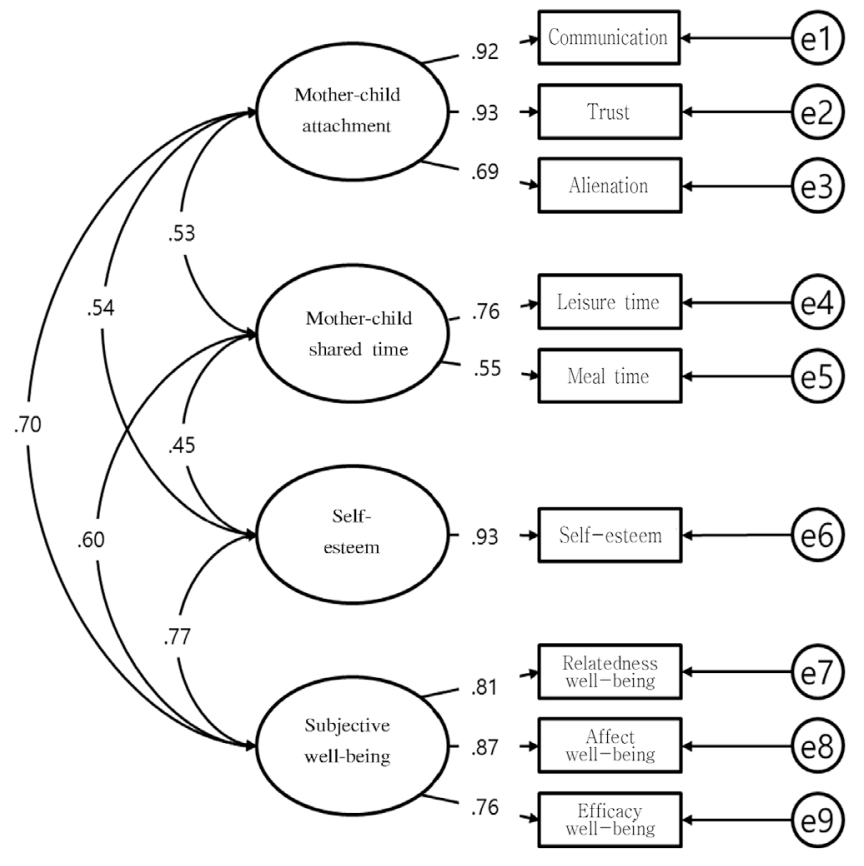

Figure 2. Factor loadings of the measurement model.

의 적합도가 확인되었다. 모-자녀 애착 및 공유시간과 자아존 중감이 아동의 주관적 안녕감에 미치는 경로는 다음과 같다 (Table 4, Figure 3). 먼저, 모-자녀 애착 및 공유시간이 아동의 주관적 안녕감에 미치는 직접 경로와 관련하여, 모-자녀 애착 $(\beta=.318, p<.001)$ 과 모-자녀 공유시간 $(\beta=.198, p<.01)$ 모두
가 아동의 주관적 안녕감에 직접적인 영향을 미치는 것으로 나타났다. 즉, 아동이 어머니와 자유롭게 소통하고 어머니에 게 대한 신뢰감을 높게 지각하고 소외감을 덜 느낄수록, 어머 니와 함께하는 시간을 많이 보낼수록, 아동은 자신의 주관적 안녕감을 높게 지각하였다. 다음으로, 모-자녀 애착 및 공유시 간이 자아존중감을 통해 아동의 주관적 안녕감에 미치는 간 접 경로와 관련하여, 모-자녀 애착 $(\beta=.411, p<.001)$ 과 모-자 녀 공유시간 $(\beta=.232, p<.001)$ 은 자아존중감에 유의한 영향 을 미쳤고, 자아존중감은 다시 아동의 주관적 안녕감에 유의 한 영향 $(\beta=.514, p<.001)$ 을 미쳤다. 즉, 아동은 어머니에 대 한 애착수준이 높고 어머니와 많은 시간을 함께 보낼수록, 자 아존중감이 높았으며, 이는 아동의 높은 주관적 안녕감으로 연결되었다.

다음으로, 모-자녀 애착 및 공유시간과 자아존중감이 아동 의 주관적 안녕감에 미치는 직 · 간접효과와 총효과를 살펴보 았다(Table 5). 그 결과, 아동의 주관적 안녕감에 영향을 미치 는 변인들의 직접적 영향력은 자아존중감 $(\beta=.514, p<.01)$, 모-자녀 애착 $(\beta=.318, p<.001)$, 모-자녀 공유시간 $(\beta=.198, p$ $<.01)$ 순으로 나타나, 자아존중감은 아동의 주관적 안녕감에 가장 큰 영향을 미쳤다. 또한 아동의 자아존중감에 영향을 미 치는 변인들의 영향력에 있어서는, 모-자녀 애착 $(\beta=.411, p<$ $.001)$ 이 모-자녀 공유시간 $(\beta=.232, p<.001)$ 보다 더 큰 영향을 미쳤다. 끝으로, 부트스트래핑(bootstrapping)을 통하여 모-자

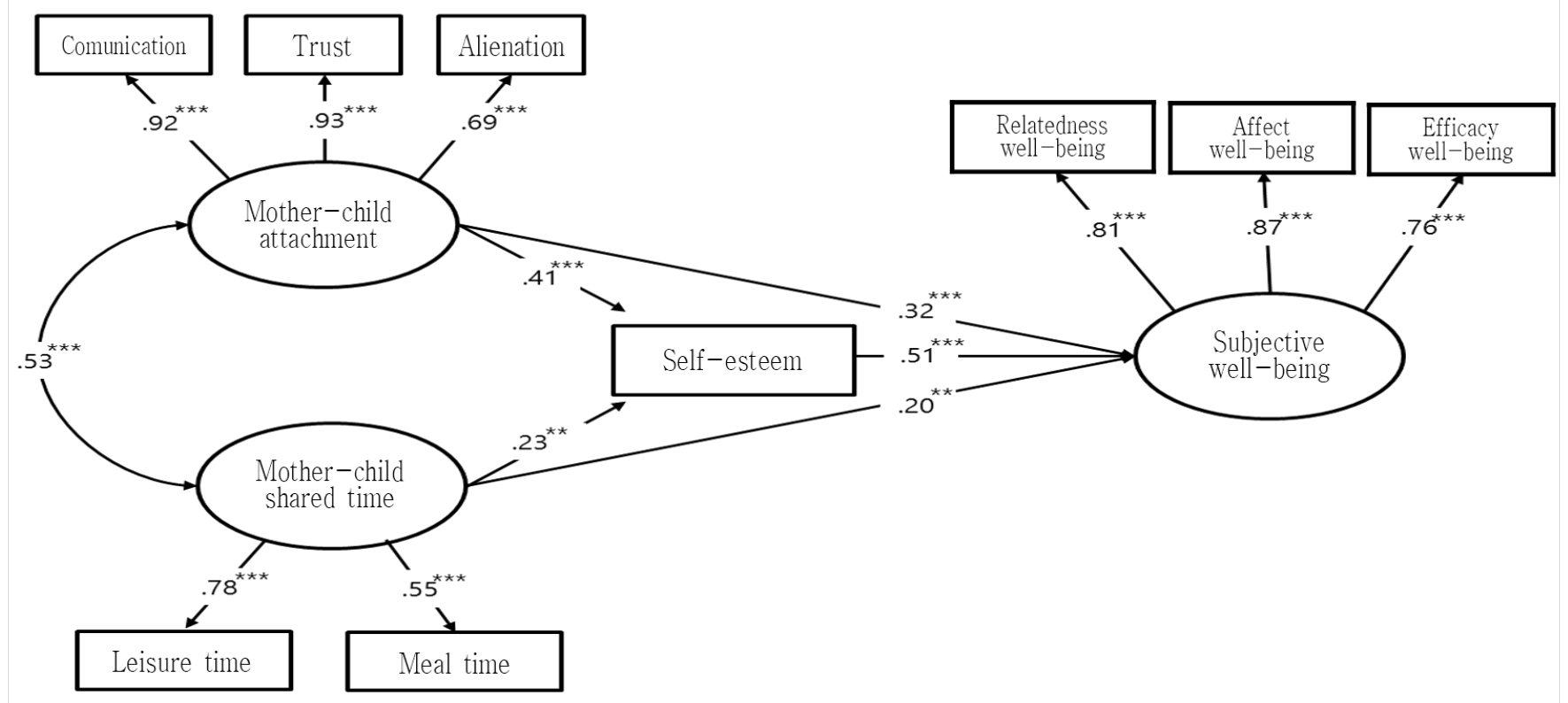

Figure 3. Direct and indirect paths from mother-child attachment and shared time to subjective well-being. 
Table 4

Path Estimates of the Latent Variables

\begin{tabular}{|c|c|c|c|c|c|c|}
\hline \multicolumn{3}{|c|}{ Path of latent variables } & $B$ & $\beta$ & S.E. & C.R. \\
\hline Mother-child attachment & $\rightarrow$ & Subjective well-being & .270 & .318 & .050 & $5.359^{* * *}$ \\
\hline Mother-child shared time & $\rightarrow$ & Subjective well-being & .158 & .198 & .054 & $2.934^{* *}$ \\
\hline Self-esteem & $\rightarrow$ & Subjective well-being & .208 & .514 & .023 & $8.897^{* *}$ \\
\hline Mother-child attachment & $\rightarrow$ & Self-esteem & .862 & .411 & .152 & $5.671^{* * *}$ \\
\hline Mother-child shared time & $\rightarrow$ & Self-esteem & .458 & .232 & .168 & $2.730^{* * *}$ \\
\hline
\end{tabular}

Note. $N=329$.

${ }^{* *} p<.01 .{ }^{* * *} p<.001$.

Table 5

Direct, Indirect, and Total Effects in the Structural Equation Model

\begin{tabular}{lllccc}
\hline \multicolumn{2}{c}{ Path from latent to latent variables } & \multicolumn{3}{c}{ Bootstrapping } \\
\cline { 3 - 5 } Mother-child attachment & $\rightarrow$ & Subjective well-being & $.318^{* * *}$ & $.211^{*}$ & $.529^{* * *}$ \\
Mother-child shared time & $\rightarrow$ & Subjective well-being & $.198^{* *}$ & $.119^{* *}$ & $.317^{* *}$ \\
Self-esteem & $\rightarrow$ & Subjective well-being & $.514^{* *}$ & .738 \\
Mother-child attachment & $\rightarrow$ & Self-esteem & $.411^{* * *}$ & $-514^{* *}$ \\
Mother-child shared time & $\rightarrow$ & Self-esteem & $.232^{* * *}$ & $.411^{* * *}$ & .325 \\
\hline
\end{tabular}

Note. $N=329$.

${ }^{*} p<.05 .{ }^{* *} p<.01 .{ }^{* * *} p<.001$.

녀 애착 및 공유시간과 아동의 주관적 안녕감 간의 관계에서 자아존중감의 간접효과의 유의성을 확인해본 결과, 모-자녀 애착 $(\beta=.211, p<.05)$ 과 모-자녀 공유시간 $(\beta=.119, p<.01)$ 모두 자아존중감을 통해 아동의 주관적 안녕감에 간접적인 영향을 미치는 것으로 나타났다. 외생변수가 내생변수의 변량 을 설명하는 정도인 다중상관치(Squared Multiple Correlation $[\mathrm{SMC}])$ 를 살펴본 결과, 모-자녀 애착 및 공유시간과 자아존중 감이 아동의 주관적 안녕감을 설명하는 정도는 약 $74 \%$ 였고, 모-자녀 애착 및 공유시간이 자아존중감을 설명하는 정도는 약 $33 \%$ 였다.

\section{논의 및 결론}

본 연구는 초등학교 5,6 학년에 재학 중인 학령 후기 남녀 아 동을 대상으로 모-자녀 애착 및 공유 시간이 아동의 주관적 안 녕감에 미치는 직접적 영향과 자아존중감을 통한 간접적 영향 을 살펴보았다. 본 연구의 결과를 요약하고 논의하면 다음과
같다.

첫째, 모-자녀 애착 수준 및 공유시간은 학령 후기 아동의 주관적 안녕감에 직접적인 영향을 미쳤다. 즉, 주 양육자인 어 머니와의 애착 수준이 높고, 어머니와 많은 시간을 함께 보 낼수록 아동은 자신의 주관적 안녕감을 높게 지각하였다. 먼 저, 모-자녀 애착과 관련한 본 연구결과는 어머니와의 애착수 준이 높을수록 학령 후기 아동의 주관적 안녕감이 높다는 연 구결과들(Y. Roh \& Kim, 2012; Seong \& Kim, 2015)과 일치한 다. 또한, 어머니와의 애착을 높게 보고할수록 학령 후기 아동 이 가정환경, 대인관계, 능력 등의 다양한 삶의 영역에서 느끼 는 행복감이 높다는 연구결과(J. Park, 2009)와도 그 맥을 같이 한다. 이러한 결과는 아동이 어머니와의 관계에서 느끼는 정 서적 유대감이나 신뢰감이 안정적일수록 자신의 정서나 능력, 그리고 자신이 맺고 있는 대인관계에 대해 긍정적으로 지각할 뿐만 아니라 긍정의 정서를 많이 경험하여, 스스로가 느끼는 주관적 안녕감이 높은 것으로 볼 수 있다. 부모-자녀 간 애착 관계는 전 생애 동안 다른 사람들과 관계를 맺는 기본적인 방 식을 구성한다는 점에서(Bowlby, 1958, 1973, 1988), 부모와의 
애착은 초기 애착이 형성되는 시기 이후에도 아동의 삶에 지 속적으로 영향을 미치는 중요한 요인으로 이를 안정적으로 유 지할 필요가 있음을 시사한다. 특히, 부모와의 애착 중에서도 어머니와의 애착이 아버지와의 애착에 비해 학령 후기 아동이 느끼는 행복감에 상대적으로 더 큰 영향을 미친다는 연구결과 (Seong \& Kim, 2015)나 아동의 주관적 안녕감에 대한 어머니 의 영향력을 강조한 연구들(Ahn et al., 2011; Joo \& Park, 2013; S. Lee et al., 2010)과 마찬가지로, 본 연구결과를 통해 또래와 많은 시간을 보내며 또래의 영향력이 점차 증가함에도 불구하 고(Yoo et al., 2015), 학령 후기 아동의 건강한 발달을 위해서는 주 양육자인 어머니와의 애착이 여전히 중요함을 확인할 수 있다. 따라서 학교나 상담 현장에서는 불안정적인 모-자녀 관 계에 관심을 가지고 이를 개선하기 위한 노력이 필요할 뿐만 아니라, 예방적 측면에서도 어머니를 대상으로 한 부모교육을 강조하는 것이 바람직할 것이다.

다음으로, 모-자녀 공유시간과 관련하여, 본 연구결과는 어 머니를 포함한 가족과 함께하는 식사시간이 많은 경우 학령 후기 아동의 정신건강에 대한 긍정적인 자각은 증가하고 부 정적인 자각은 감소한 연구결과(Sung \& Kwon, 2010)와 일치 하며, 어머니와 자녀가 함께하는 가족의 여가시간이 많을수 록 청소년의 유능감, 지지감, 향상감과 같은 심리적 복지감이 높다고 보고한 연구결과(J. Lee, 2012)와도 유사하다. 또한 어 머니와 자녀가 함께하는 식사시간이나 여가시간이 많을수록, 자녀가 긍정적인 정서와 소속감을 더 많이 지각하는 반면, 스 트레스와 부정적인 정서는 덜 경험한다고 보고한 연구결과 (Offer, 2013)와도 비슷한 맥락이다. 즉, 어머니와 함께하는 시 간이 많을수록 삶에 대한 만족도와 긍정적인 정서를 더 많이 경험하는 것으로 볼 수 있다. 이는 어머니와 함께하는 시간이 많아지면서 자연스레 대화하거나 신체적인 접촉의 기회가 많 아지고, 아동이 주 양육자와의 친밀감을 경험할 수 있는 시간 을 통해 삶의 전반에 느끼는 안녕감이 높아진 것으로 해석된 다. 특히, 어머니와 함께 하는 시간을 통해 전달되는 부모의 관 심은 아동이 다양한 상황에서의 어려움을 해결할 수 있는 정 서적 자원이 되었을 가능성도 내포한다. 이와 유사하게 건강 한 가족의 아동에게서 심리적 안녕감이 높게 나타나거나(Wi, 2012), 가족 구성원 간의 정서적 유대감이 높을수록 아동은 자 신의 행복감을 더 높게 지각한다는 연구결과(Lim, 2012)를 통 해서도, 공유하는 양적인 시간을 건강하게 함께 하는 가족이 라면 서로 간에 친밀감과 유대감을 더욱 느끼게 되고, 이는 아 동 스스로가 소속감이나 자신의 가치에 대해 더욱 높게 지각 할 수 있을 것이다. 아동의 건강한 발달을 위해서는 부모와 함
께하는 질적인 시간이 매우 중요한데(Doh, 2012), 본 연구결 과를 통해 어머니와 공유하는 양적인 시간 동안 질적인 시간 이 함께 병행된다면, 부모-자녀관계의 개선 뿐 아니라 아동의 건강한 발달에 더욱 도움이 되리라 사료된다. 무엇보다도, 본 연구결과는 또래에 대한 애정과 의존도가 늘어나는 학령 후기 에도 여전히 어머니와의 관계 속에서 경험하는 애착이나 공유 시간의 중요성을 확인하였다.

한편, 모-자녀 애착이 모-자녀 공유시간 보다 학령 후기 아 동의 주관적 안녕감에 대해 상대적으로 더 큰 영향력을 보인 점은 흥미로운 결과이다. 두 가지 변인의 영향력을 살펴본 연 구가 드물어 본 연구결과를 직접적으로 비교하기에는 어려 움이 따른다. 그러나 부모와의 애착이 아동의 주관적 안녕감 에 미치는 영향에 관한 선행 연구결과들(J. Park, 2009; Y. Roh \& Kim, 2012; H. Shin, 2010)이나 주 양육자와의 관계에서 경 험하는 안정된 애착이 이후의 대인관계의 원형으로 작용된다 는 연구결과(Williams \& Kelly, 2005)를 통해서 애착의 영향력 이 얼마나 큰지를 확인할 수 있다. 따라서 학령 후기 아동의 주 관적 안녕감을 높이기 위해서는 아동이 주 양육자인 어머니 와 안정된 애착을 형성함으로써, 어머니에 대한 신뢰를 가지 고 어머니로부터 수용과 애정을 느낄 수 있도록 도와야 할 것 이다. 그럼에도 불구하고, 모-자녀 공유시간이 아동의 주관적 안녕감에 미치는 영향력을 보건대, 아동과 어머니가 함께 보 내는 시간의 중요성 또한 간과할 수는 없다. 어머니가 바쁜 일 상 속에서도 자녀와 함께 하는 시간을 소홀히 하지 않고, 각 가 정이 처한 상황에 맞춰 자녀와 함께하려고 노력할 때, 아동의 주관적 안녕감은 더욱 높아질 것이다. 동시에, 모-자녀 애착의 상대적 중요성을 감안할 때, 단순히 물리적으로 같은 장소에 서 같은 활동을 하는 것에서 나아가 어머니와 아동이 서로를 보다 잘 이해할 수 있는 기회로 활용될 때, 모-자녀 공유시간 이 아동의 주관적 안녕감에 미치는 효과는 더욱 커질 것이다.

둘째, 모-자녀 애착 및 공유시간은 학령 후기 아동의 자아 존중감을 통해 아동의 주관적 안녕감에 간접적인 영향을 미쳤 다. 즉, 모-자녀 애착 수준과 모-자녀 공유시간이 충분한 아동 일수록 자아존중감이 높았으며, 이러한 높은 자아존중감은 아 동의 높은 주관적 안녕감으로 이어졌다. 이러한 결과는 부모 애착이 자아존중감을 통해서 청소년의 삶의 만족도에 영향을 준다는 연구결과(Sihn et al., 2012)나 부모 애착 수준이 높을수 록 학령 후기 아동의 자아존중감이 높았으며, 높은 자아존중 감은 아동의 높은 정서적, 심리적, 사회적 안녕감으로 연결된 다는 연구결과(H. Lee \& Moon, 2012)와도 유사한 맥락에서 이 해된다. 또한, 자아의 조절능력과 인지능력을 포괄하는 개념 
인 자아탄력성이 다양한 스트레스 상황에서 스스로를 조절할 수 있는 자아의 적응능력이라는 점에서(J. H. Block \& Block, 1980), 모와의 애착이 학령 후기 아동의 자아탄력성을 통해 심 리적 안녕감에 영향을 미치는 연구결과(Ahn et al., 2011)와도 그 맥을 같이한다. 즉, 어머니와 긍정적인 애착을 형성한 아동 은 자신의 가치와 능력을 높이 평가하며, 이는 타인과의 관계 에서도 긍정적인 태도를 가지고 유연하게 대처함으로써 다양 한 환경적 요구에 적응하는 능력이 높아지면서 아동이 자신의 삶의 질에 대한 주관적 평가인 안녕감에도 긍정적인 영향을 미치게 되는 것으로 보인다. 모-자녀 애착과 달리 모-자녀 공 유시간이 자아존중감을 통해 학령 후기 아동의 주관적 안녕감 에 미치는 영향을 살펴본 연구는 거의 없으나, 아동에게 중요 한 대상인 어머니와 함께하는 시간이 많을수록 아동은 긍정적 인 정서를 더 많이 경험하며 자신을 소중하고 가치롭게 여기 게 되고 나아가 자신의 삶에 대한 안녕감도 높게 지각하리라 사료된다.

이상과 같은 모-자녀 애착 및 공유시간, 자아존중감, 주관 적 안녕감 등 세 변인 간의 경로를 각각의 경로로 나누어 살펴 보면, 모-자녀 애착 및 공유시간은 학령 후기 아동의 자아존중 감에 미쳐, 어머니와 안정적인 애착을 경험하고 함께 하는 시 간이 많을수록 아동은 자신을 보다 가치롭게 지각하였다. 이 러한 결과는 어머니와 긍정적인 관계를 맺고 어머니에 대한 애착을 높게 보고하며, 어머니로부터 충분한 지지를 받는다고 느끼는 아동.청소년의 자아존중감이 더욱 높다는 선행 연구 결과들(Bulanda \& Majumdar, 2009; Parker \& Benson, 2004)과 일치한다. 또한 등하교시나 잠자리에 들기 전에 어머니가 집 에 함께 있으며, 어머니와 같이 하는 활동이 많은 청소년일수 록 자아존중감이 보다 높다는 연구결과(Bulanda \& Majumdar, 2009)와도 유사하다. 자아존중감이 타인과의 상호작용 속에 서 그들로부터 받는 존중, 수용, 관심을 바탕으로 형성된다는 점에서(Y. Roh, 2005), 자아존중감의 발달을 위해서는 아동에 게 가장 중요한 타인이라고 할 수 있는 어머니와의 안정된 관 계 속에서 경험하는 정서적 지지와 격려가 매우 중요함을 알 수 있다. 특히, 학령기에 형성된 자아존중감은 아동의 이후 발 달에 다양한 영향을 미침은 물론, 생애 전반에 걸쳐 상당히 안 정적인 특성을 가지므로(J. Block \& Robinson, 1993), 학령 후 기 아동의 건강한 성장과 적응을 위해서는 자아존중감 증진 에 보다 많은 관심을 기울여야 할 것이다. 또한, 모-자녀 애착 은 모-자녀 공유시간보다 자아존중감에 상대적으로 더 큰 영 향을 미쳤다. 이는 또래의 영향력이 많아지는 학령 후기에도 (K. L. Park \& Kim, 2001), 아동의 자아존중감의 발달을 위해서
는 모-자녀 간의 애정적이고 신뢰로운 관계를 형성하는 것이 매우 중요함을 알 수 있다. 따라서 학령 후기 아동이 자신에 대 해 긍정적인 가치를 보다 많이 경험하기 위해서는 모-자녀의 건강한 애착형성을 위한 다양한 형태의 교육이나 중재적 노력 이 매우 중요하지만, 아동이 자율성과 유능감을 경험할 수 있 도록 함께하는 공유시간 동안 어머니가 아동을 격려하고 칭찬 하는 등의 지도방법을 고려할 필요성도 시사한다.

다음으로, 학령 후기 아동의 자아존중감은 주관적 안녕감 에도 영향을 미쳐, 자아존중감이 높은 아동은 자신의 주관 적 안녕감을 높게 지각하였다. 이는 아동.청소년이 자신의 능력을 높이 평가하며, 스스로에 대해 긍정적으로 지각할수 록 주관적 안녕감이 더 높은 경향이 있다고 보고한 여러 연 구결과들(Choi, 2010; S. Hong, 2008; H. Lee \& Moon, 2012; Mccullough, Huebner, \& Laughlin, 2000)과 일치한다. 또한 자 아존중감이 높을수록 청소년의 우울이나 외로움과 같은 부정 적 심리 상태가 더 적게 나타난다는 것을 밝힌 연구결과(J. S. $\mathrm{Kim}$, Jeon, \& Lee, 2009)와도 유사한 맥락이다. 즉, 자아존중감 이 높은 사람은 자기이해와 수용능력이 높고, 스스로를 존중 하며 가치 있는 사람으로 지각하게 되는데, 이는 아동이 경험 하게 되는 다양한 상황을 자신감 있게 대처하고 적응해 나가 면서 자신이 경험하는 삶의 질을 긍정적으로 평가하는 것으 로 보인다. 이러한 결과는 학령 후기 아동의 건강한 발달에 중 요한 역할을 하는 스스로에 대한 긍정적인 지각이 아동이 느 끼는 주관적 안녕감과도 밀접한 관련을 가짐을 알려줌과 동시 에, 아동의 주관적 안녕감을 높이기 위해 그들의 자아존중감 을 향상시키는 일이 선행되어야 함을 강조한다.

한편, 자아존중감은 모-자녀 애착과 공유시간에 비해 학령 후기 아동의 주관적 안녕감에 상대적으로 보다 큰 영향력을 보여, 모-자녀관계라는 환경적 요인보다 개인 내적 요인인 자 아존중감이 아동의 주관적 안녕감을 형성하는 데 보다 큰 비 중을 차지한다는 것을 알 수 있다. 이는 학령 후기 아동의 주관 적 안녕감을 높이기 위해서는 모-자녀관계의 개선뿐만 아니 라, 아동이 많은 시간을 보내는 학교 환경에서의 경험을 비롯 하여 아동의 자아존중감에 직접적인 영향을 미칠 수 있는 다 양한 요인들에 대한 학문적 관심이 필요함을 시사한다.

결론적으로, 모-자녀 애착 및 공유시간은 학령 후기 아동의 주관적 안녕감에 직접적인 영향을 미쳤으며, 자아존중감을 통 해 간접적으로도 영향을 미쳤다. 이는 학령 후기 아동의 주관 적 안녕감을 높이기 위해서는 긍정적인 모-자녀관계를 비롯 하여 아동 자신의 높은 자아존중감 또한 매우 중요함을 의미 한다. 바람직한 모-자녀 관계 형성을 위한 적절한 중재는 아동 
의 자아존중감을 향상시킴은 물론, 나아가 아동의 주관적 안 녕감을 높일 수 있는 가장 효과적인 방안이 될 것이다. 특히, 아동의 주관적 안녕감에 미치는 직접적 영향력이 자아존중감, 모-자녀 애착, 모-자녀 공유시간의 순으로 나타남으로써, 자아 존중중감의 상대적 영향력을 확인하였다. 어머니와의 불안정 애착으로 인해 주관적 안녕감이 낮은 아동들을 위해 자아존중 감을 강화하거나 향상시킬 수 있는 프로그램의 제공이나 행정 적 지원이 마련되어야 할 것이다.

본 연구의 제한점과 후속 연구를 위한 제언을 하면 다음과 같다. 먼저, 본 연구는 모-자녀 공유시간의 개념을 동일한 장 소에서 동일한 활동에 모-자녀가 함께 참여하는 것에 초점을 두어, 공유시간의 질적인 측면은 다루지 못한 한계가 있다. 즉, 모-자녀가 함께 시간을 보내면서 어떻게 상호작용하는지, 아 동이 그 활동에 만족하는지 등에 따라 모-자녀가 시간을 함께 보내더라도, 그 의미는 달라질 수 있음을 반영하지 못하였다. 따라서 후속 연구에서는 모-자녀 공유시간의 의미를 보다 자 세히 읽어내기 위한 질적 연구방법을 활용하는 것도 바람직할 것이다. 이 외에도, 주 양육자로서의 어머니 역할뿐만 아니라 공동양육자로서의 아버지 역할의 중요성을 고려하건대, 부자녀 애착을 포함하여 살펴보는 것도 흥미로운 후속 연구가 될 것이다.

이러한 제한점에도 불구하고 본 연구는 다음과 같은 몇 가 지 의의를 가진다. 먼저, 본 연구는 모-자녀관계가 학령 후기 아동의 주관적 안녕감에 미치는 영향력을 살펴보기 위해, 모자녀 애착과 모-자녀 공유시간이라는 두 변인을 동시에 고려 함으로써, 모-자녀관계의 질적인 측면과 양적인 측면의 상대 적인 영향력을 비교하였다. 또한, 본 연구는 학령 후기 아동의 주관적 안녕감을 향상시키기 위해서는 환경적 요인으로서의 모-자녀관계를 개선시킴과 동시에, 개인 내적 요인으로서의 자아존중감 증진을 위한 노력이 필요함을 확인하였다. 본 연 구결과는 학령 후기 아동이 보다 건강하고 행복하게 자라날 수 있도록 돕기 위한 부모교육 프로그램과 학령 후기 아동의 자아존중감 관련 프로그램의 기초자료로 활용될 수 있을 것 이다.

\section{Acknowledgements}

This study was supported by the National Research Foundation of Korea Grant funded by the Korean Government (NRF2013S1A3A2055259).

\section{Notes}

This article is a part of the first author's master's thesis submitted in 2014.

\section{Conflict of Interest}

No potential conflict of interest relevant to this article was reported.

\section{References}

Ahn, J., Oh, M., \& Kim, J. (2011). The pathways from attachment to children's psychological well-being: The mediating effects of children's ego-resilience and peer support. Korean Journal of Child Studies, 32(6), 63-79.

Ainsworth, M. D. S., Blehar, M. C., Waters, E., \& Wall, S. (1978). Patterns of attachment: A psychological study of the strange situation. Hillsdale, NJ: Erlbaum.

Armsden, G. C., \& Greenberg, M. T. (1987). The inventory of parent and peer attachment: Individual differences and their relationship to psychological well-being in adolescence. Journal of Youth and Adolescence, 16(5), $427-$ 454. doi:10.1007/BF02202939

Bak, B. G., \& Hong, S. P. (2004). Development and validation of a subjective well-being scale. The Korean Journal of Educational Psychology, 18(3), 159-175.

Bak, B. G., \& Song, J. H. (2007). Multidimensional $2 \times 3$ factor structure of subjective well-being. The Korean Journal of Educational Psychology, 21(3), 591-611.

Baumeister, R. F., Campbell, J. D., Krueger, J. I., \& Vohs, K. D. (2003). Does high self-esteem cause better performance, interpersonal success, happiness, or healthier lifestyles? Psychological Science in the Public Interest, 4(1), 1-44. doi:10.1111/1529-1006.01431

Bea, J. Y., Doh, H., Rhee, S. H., \& Shin, J. H. (2015). The effects of maternal parenting behavior, relationships with friends, and relationships with teachers on the subjective well-being of children in late childhood. Korean Journal of Child Studies, 36(6), 59-83. doi:dx.doi.org/10.5723/ KJCS.2015.36.6.59

Block, J., \& Robinson, R. W. (1993). A longitudinal study of consistency and change in self-esteem from early adolescence to early adulthood. Child Development, 64(3), 909-923. doi: $10.2307 / 1131226$

Block, J. H., \& Block, J. (1980). The role of ego-control and egoresiliency in the organizatiion of behavior. In W. A. Collins 
(Ed.), The Minnesota symposia on child psychology. Hillsdale, NJ: Erlbaum.

Bowlby, J. (1958). The nature of child's tie to his mother. International Journal of Psychoanalysis, 39, 350-373.

Bowlby, J. (1973). Attachment and loss, Vol. 2: Separation. New York: Basic Books.

Bowlby, J. (1988). A secure base: Parent-child attachment and healthy human development. New York: Basic Books.

Bradburn, N. M. (1969). The structure of psychological well-being. Chicago: Aldine.

Browne, M. W., \& Cudeck, R. (1993). Alternative ways of assessing model fit. In K. A. Bollen \& J. S. Long (Eds.), Testing structural equation models (pp. 111-135). Beverly Hills, CA: Sage.

Bulanda, R. E., \& Majumdar, D. (2009). Perceived parent-child relations and adolescent self-esteem. Journal of Child and Family Studies, 18(2), 203-212. doi:10.1007/s10826-0089220-3

Campbell, A. (1981). The sense of well-being in America: Recent patterns and trends. New York: McGraw-Hill.

Cho, H. (2011). The effects of social support, hope, depression, and academic achievement on psychological well-being. Korean Journal of Educational Psychology, 25(1), 153-174.

Cho, S., \& Jin, M. (2015). The mediating effects of optimism in the relationship between parental attachment and psychological well-being in adolescents. Asian Journal of Child Welfare and Development, 13(1), 95-112.

Choi, M. (2010). The relations of children' stress, self-esteem, and subjective well-being. Journal of the Korean Home Economics Association, 48(10), 65-75.

Crouter, A. C., Head, M. R., McHale, S. M., \& Tucker, C. J. (2004). Family time and the psychosocial adjustment of adolescent siblings and their parents. Journal of Marriage and Family, 66(1), 147-162.

Diener, E. (1984). Subjective well-being. Psychological Bulletin, 95(3), 542-575.

Diener, E. (1996). Works on subjective well-being. Journal of Macromarketing, 16, 135-137.

Diener, E., \& Diener, M. (1995). Cross-cultural correlates of life satisfaction and self-esteem. Journal of Personality and Social Psychology, 68(4), 653-663. doi:10.1007/978-90-481-23520_4

Diener, E., Emmons, R. A., Larsen, R. J., \& Griffin, S. (1985). The satisfaction with life scale. Journal of Personality Assessment, 49(1), 71-75. doi:10.1207/s15327752jpa4901_13

Doh, H. (2012). The first parenting book. Seoul: Knowledge Channel.

Eisenberg, M. E., Olson, R. E., Neumark-Sztainer, D., Story, M., \& Bearinger, L. H. (2004). Correlations between family meals and psychosocial well-being among adolescents.
Archives of Pediatrics \& Adolescent Medicine, 158(8), 792798. doi:10.1001/archpedi.158.8.792.

Harter, S. (1982). The perceived competence scale for children. Child Development, 53(1), 87-97. doi:10.2307/1129640

Hong, S. (2000). The criteria for selecting appropriate fit indices in Structural Equation Modeling and their rationales. The Korean Journal of Clinical Psychology, 19(1), 161-177.

Hong, S. (2008). Effects of social competence on children's selfconcept and subjective well-being. The Journal of Child Education, 17(2), 311-321.

Jeon, G. Y., \& Lim, J. Y. (2002). The effect of attachment styles and social support on the elderly's subjective well-being. Journal of the Korea Gerontological Society, 22(3), 173-191.

Jhon, Y., \& Yoo, M. (2014). The mediating effect of child's playfulness in the relationship between maternal attachment and a child's school adjustment. The Journal of Korea Open Association for Early Childhood Education, 19(1), 187-202.

Jo, G., \& Cho, J. (2004). Psychological well-being of employed and nonemployed married women: Gender-role attitude, life event stress, and marital satisfaction as a moderator. Korean Journal of Woman Psychology, 9(3), 27-41.

Joo, J. Y., \& Park, S. Y. (2013). The effects of mother's optimism, parenting behaviors and their child's optimism and the effects on a child subjective well-being. Korean Journal of Child Studies, 34(3), 21-38. doi:dx.org/10.5723/ KJCS.2013.34.3.21

Jung, H. S. \& Park, S. Y. (2010). The effects of family climate, peer support and self-esteem on children's self-regulation. Korean Journal of Child Studies, 31(1), 19-33.

Kang, S., \& Chang, S. (2013). The mediating effect of character strengths in the relationship between social supports and subjective well-being: Focused on community child centers. Korean Journal of Counseling, 14(4), 2395-2416.

Karademas, E., Peppa, N., Fotiou, A., \& Kokkevi, A. (2008). Family, school and health in children and adolescents. Journal of Health Psychology, 13(8), 1012-1020. doi:10.1177/1359105308097965

Kim, C., Han, E., \& Cho, M. (2013). A structural analysis of parental attachment, emotional intelligence, self-efficacy, and school adjustment perceived by elementary school students. Journal of Children's Literature and Education, 14(1), 209-229.

Kim, G. S. (2011). New Amos 16.0 analysis of structural equation model. Seoul: Hannarae Publishing.

Kim, J. S., Jeon, Y. S., Lee, C. W. (2009). The influence of attachment, differentiation, and self-esteem on adolescent depression. Journal of Korean Family Therapy, 17(1), 209224.

Kim, M., Kim, H., \& Cha, K. (2001). Analyses on the construct of psychological well-being (PWB) of Korean male and female 
adults. Korean Journal of Social and Personality Psychology, 15(2), 19-39.

Kim, S., \& Lee, S. (2014). The influences of children's mother attachment on maladjustment behavior: Mediating effects of self-esteem and the quality of peer relationship. The Journal of Play Therapy, 18(2), 33-51.

Kim, Y. H. (2005). The relationship between open communication of the parents and children's behavior problem: Self-esteem and self-control as a mediating variable (Unpublished master's thesis). Sookmyung Women's University, Seoul, Korea.

Ko, Y. (2008). The relationship among father, mother, peer attachment and subjective well-being in middle school students. The Journal of Yeolin Education, 16(2), 111-131.

Koo, K., \& Kim, S. (2014). Effects of family strength on subjective well-being perceived by elementary students: Mediating effect of self-differentiation and moderating effect of gender difference. Korean Journal of Youth Studies, 21(6), 281-307.

Kwon, J. E. (2011). The study on family leisure activities, satisfaction and constraints of childhood family (Unpublished master's thesis). Ulsan University, Ulsan, Korea.

Lee, H., \& Moon, S. (2012). A structural analysis of school-aged children's well-being and its related variables. Journal of Korean Home Management Association, 30(3), 45-57. doi:10.7466/JKHMA.2012.30.3.045

Lee, H. J., Lee, M., \& Choe, I. (2008). Validation of a well-being scale of adolescent in Korea. Korean Journal of Educational Psychology, 22(1), 301-315.

Lee, J. (2012). The effect of family leisure activities and leisure function on adolescent psychological well-being. Korean Journal of Counseling and Psychotherapy, 3(2), 21-34.

Lee, J., \& Lee, Y. (2007). The effects of perceived parental conflict, maternal behavior, and social support on children's subjective well-being: A structural equation modeling analysis. Korean Journal of Developmental Psychology, 20(4), 33-58.

Lee, S. \& Choi, J. M. (2003). Influences of maternal child rearing behaviors and peer acceptance on children's self esteem. Family and Environment Research, 41(2), 31-42.

Lee, S., Doh, H., Choi, M., \& Ku, S. (2010). Exploring pathways from mothers' beliefs to children's subjective well-being: The mediating effects of children's private after-school education and stress levels. Korean Journal of Child Studies, 31(3), 255-272.

Lee, S., \& Lee, K. (1998). A study on the time shared with parents and children. Journal of Korean Home Management Association, 16(2), 123-136.

Lim, E. J. (2012). The effects of family functioning, ego-resilience, and peer relationship on children's subjective well-being (Unpublished master's thesis). Ewha Womans University, Seoul, Korea.
Mccullough, G., Huebner, E. S., \& Laughlin, J. E. (2000). Life events, self-concept and adolescents' positive subjective well-being. Journal of Psychology in the Schools, 37(3), 281-290. doi:10.1002/(SICI)15206807(200005)37:3<281::AID-PITS8>3.0.CO;2-2

Min, H. (2008). The relationship between parent's conflict, paternal/maternal grandmother's psychological support and school-aged children's well-being. Journal of Korean Home Management Association, 26(2), 33-41.

Montemayor, R., \& Eisen, M. (1977). The development of selfconceptions from childhood to adolescence. Developmental Psychology, 13(4), 314-319.

Noh, J., \& Shin, N. (2014). The moderating effect of optimistic thinking on the relationship between sixth-grade elementary school children's daily hassles and subjective well-being. Korean Journal of Child Studies, 35(3), 137-156. doi:10.5723/KJCS.2014.35.3.137

Offer, S. (2013). Family time activities and adolescents' emotional well-being. Journal of Marriage and Family, 75(1), 26-41. doi:10.1111/j.1741-3737.2012.01025.x

Ok, J. (1998). The relationship between attachment security and depression in adolescence: Focusing on the mediating effect of perceived competence (Unpublished master's thesis). Ewha Womans University, Seoul, Korea.

Park, E., \& Choi, S. (2014). The study on a validation of wellbeing manifestation measure scale in Korea. Korean Journal of Youth Studies, 21(8), 495-511.

Park, H. C., Kim, S. B., \& Hong, D. A. G. (2011). The effects of family functions and social supports on happiness: Children's perspectives. Journal of Family Relations, 16(3), 167-193.

Park, H. K., \& Kwon, K. I. (2012). The effect attachment and separation-individuation on the elementary students' internet addiction: Meditated by self-esteem. Korean Journal of Youth Studies, 19(12), 301-329.

Park, J. (2009). The relationship between elementary students' sense of happiness and their attachment to their parents and social support (Unpublished master's thesis). Suncheon National University of Education, Suncheon, Korea.

Park, K. L., \& Kim, K. Y. (2001). Effects of mother's support and peer acceptance on children's self-esteem: The moderating effects of a best friend's support. Korean Journal of Child Studies, 22(4), 85-97.

Parker, J. S., \& Benson, M. J. (2004). Parent-adolescent relations and adolescent functioning: Self-esteem, substance abuse, and delinquency. Adolescence, 39(155), 519-530.

Roh, Y. (2005). A analysis on the relationship between psychological family environment perceived by children and self-esteem \& school adjustment (Unpublished master's thesis). Jeonju National University of Education, Jeonju, Korea. 
Roh, Y., \& Kim, H. (2012). The mediating effect of optimism on the relationship between parents attachment and subjective well-being in upper grade elementary school students. Korean Journal of Counseling, 13(6), 2625-2640.

Rosenberg, M. (1965). Society and the adolescent self image. Princeton, NJ: Princeton University Press.

Ryff, C. D. (1989). Happiness is everything, or is it? Explorations on the meaning of psychological well-being. Journal of Personality and Social Psychology, 57(6), 1069-1081.

Seong, D. G., \& Kim, C. K. (2015). The effects of parental attachment, peer attachment, and teacher attachment on children's happiness in elementary school students in higher grades: With a focusing on the mediating effect of selfregulation abilities. Korean Journal of Child Studies, 36(4), 129-142. doi:dx.doi.org/10.5723/KJCS.2015.36.4.129

Shin, D. C., \& Johnson, D. M. (1978). Avowed happiness as an overall assessment of the quality of life. Social Indicators Research, 5(1), 475-492. doi:10.1007/BF00352944

Shin, H. (2010). Impact of children's attachment and ego resilience on subjective wellbeing (Unpublished master's thesis). Chungnam National University, Daejeon, Korea.

Sihn, M., Jeon, S. H., \& Yoo, M. S. (2012). Analysis of the structural relationship between social relationships, self esteem, life satisfaction, and school adjustment in early adolescents. Korean Journal of Child Studies, 33(1), 81-92.

Sung, S. J., \& Kwon, S. (2010). Effect of eating with family or alone on the self-rated mental or physical health: The elementary school children in Daejeon area. Korean Journal of Community Nutrition, 15(2), 206-226.

Watson, D., \& Clark, L. A. (1984). Negative affectivity: The disposition to experience aversive emotional states.
Psychological Bulletin, 96(3), 465-490.

Wi, J. H. (2012). An analysis of structural relations among children's perceived family strength, self-resilience, social support, stresscoping behavior, and psychological well-being (Unpublished doctoral dissertation). Dong-A University, Busan, Korea.

Williams, S. K., \& Kelly, F. D. (2005). Relationships among involvement, attachment, and behavioral problems in adolescence: Examining father's influence. The Journal of Early Adolescence, 25(2), 168-196. doi: $10.1177 / 0272431604274178$

Yoo, S., Park, B., \& Doh, H. (2015). Pathways from peer relationships to subjective well-being through self-esteem in late childhood. Korean Journal of Child Studies, 36(2), 5574. doi:dx.doi.org/10.5723/KJCS.2015.36.2.55

Youm, Y. S., Kim, K. M., Lee, E. J., \& Lee, S. W. (2015). Korean children's and adolescents' happiness index: An international comparative study. Retrieved from http://www.korsofa.org/ bbs/board.php?bo_table=data\&wr_id=73

\section{ORCID}

Ji-A Bae http://orcid.org/0000-0003-1414-5537

Hyun-Sim Doh http://orcid.org/0000-0002-7393-4520

Bokyung Park http://orcid.org/0000-0002-8194-1675

Min-Jung Kim http://orcid.org/0000-0002-6591-9419

Received February 29, 2016

Revision received April 21, 2016

Accepted April 23, 2016 